\title{
TURDUS COCHINCHINENSIS.
}

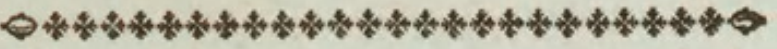

CHARACTER GENERICUS.

Rostrum tereti-cultratum : mandibula superiore apice deflexo, emarginato.

Nares nudæ superne membranula semitectæ. Faux ciliata.

Lingua lacero-emarginata.

$$
\text { Lin. Syst. Nat. p. } 291 .
$$

CHARACTER SPECIFICUS, Ë.

TURDUS viridis, gula nigra arcu flavo cincta.

TURDUS COCHINCHINENSIS. T. viridis, maculis ad basin rostri utrinque cœruleis, facie mento et gula nigris, hac arcu flavo cincta.

Lin. Syst. Nat. Gmel. p. 825.

$\mathrm{T}$. viridis loris gulaque nigris, sub gula lunula lata flava, ad basin rostri utrinque macula corulea.

Lath. ind: orn. p. $35 \%$.

Cochinchinam incolit pulchra hæc species, et magnitudine vera in tabula exprimitur.

E. 


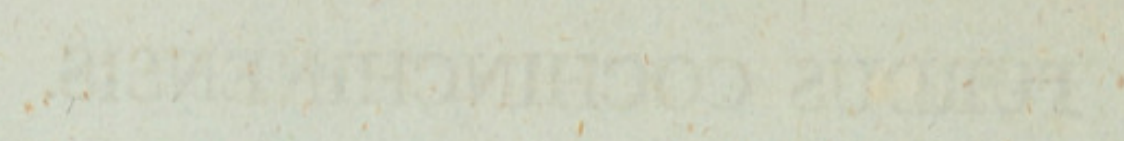




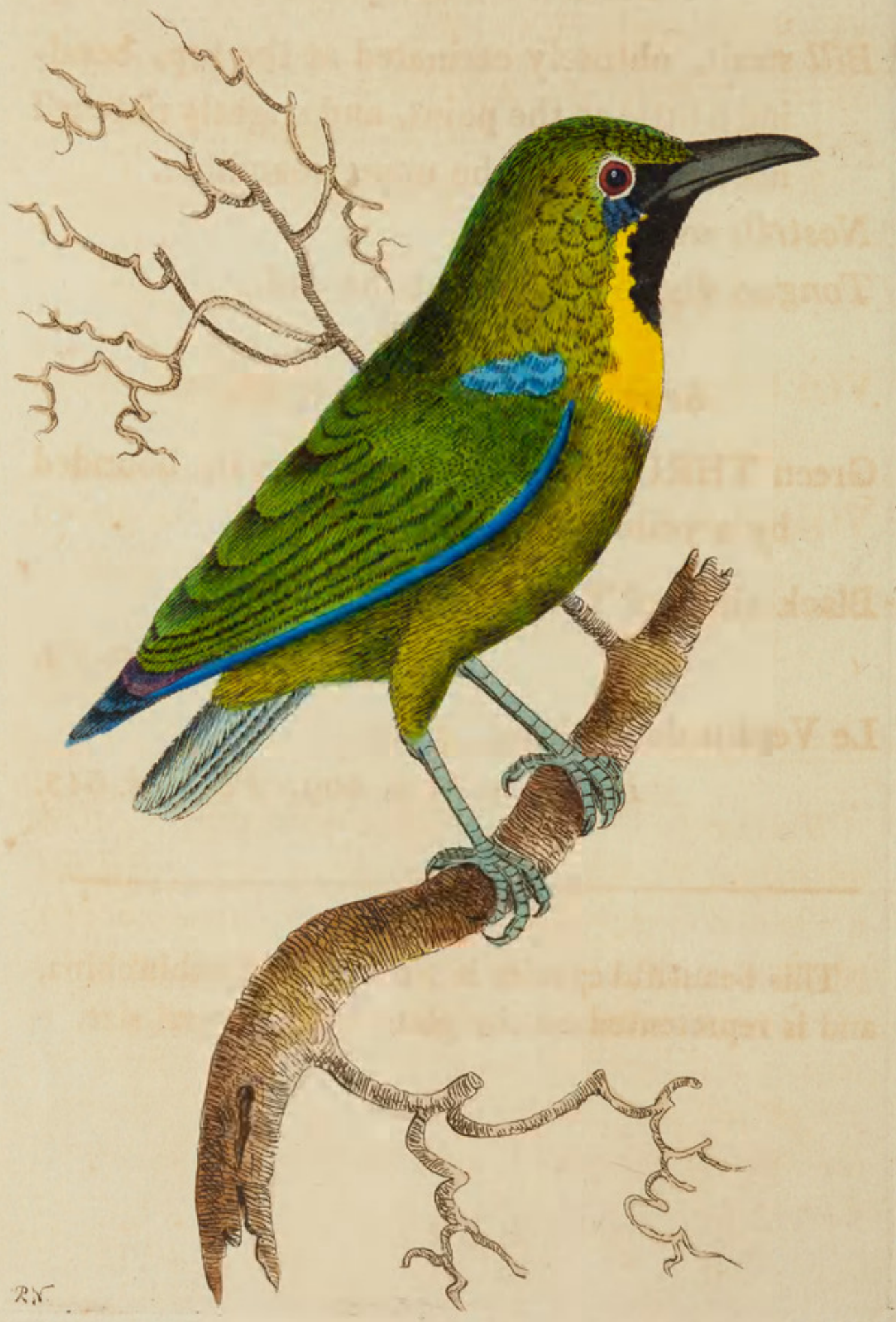




\section{THE}

\section{COCHINCHINA THRUSH.}

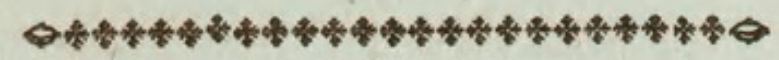

GENERIC CHARACTER.

Bill strait, obtusely carinated at the top, bending a little at the point, and slightly notched near the end of the upper mandible.

Nostrils oval.

Tongue slightly jagged at the end.

SPECIFIC CHARACTER, EC.

Green THRUSH, with black throat, bounded by a yellow crescent.

Black-chinned THRUSH.

Lath. syn. 2. p. 79.

Le Verdin de la Cochinchine.

Buff. ois. 3. p. 409. Pl. Enl.643.

This beautiful species is a native of Cochinchina, and is represented on the plate in its natural size.

E 2 


\section{$2 \mathrm{BHL}$ Biodiversity Heritage Library}

Shaw, George. 1803. "The Cochinchina Thrush, Turdus cochinchinensis [PI. 557]." The Naturalist's Miscellany 14(CLXI), https://doi.org/10.5962/p.311002.

View This Item Online: https://www.biodiversitylibrary.org/item/278723

DOI: https://doi.org/10.5962/p.311002

Permalink: https://www.biodiversitylibrary.org/partpdf/311002

\section{Holding Institution}

Museums Victoria

\section{Sponsored by}

Atlas of Living Australia

\section{Copyright \& Reuse}

Copyright Status: Public domain. The BHL considers that this work is no longer under copyright protection.

This document was created from content at the Biodiversity Heritage Library, the world's largest open access digital library for biodiversity literature and archives. Visit BHL at https://www.biodiversitylibrary.org. 